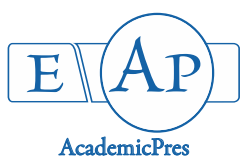

Wangpan T et al. (2021)

Notulae Scientia Biologicae

Volume 13, Issue 2, Article number 10894

DOI: $10.15835 / \mathrm{nsb} 13210894$

Research Article

\title{
Anti-proliferating activity of some toxic and medicinal plants used by Wancho tribe of Arunachal Pradesh, India
}

\author{
Tonlong WANGPAN ${ }^{1 *}$, Athai WANGPAN ${ }^{1}$, Luk B. CHETRY², \\ Sumpam TANGJANG ${ }^{1}$
}

\begin{abstract}
${ }^{1}$ Rajiv Gandhi University, Department of Botany, Rono Hills, Doimukh-791112, Arunachal Pradesh, India; twangpan@gmail.com; (*corresponding author); youngeyxenwa143@gmail.com; sumpam@gmail.com

2Jagannath Barooah College (Autonomous), Department of Zoology,Jorhat-785001, Assam, India; lukbahadurchetry@gmail.com
\end{abstract}

Medicinal plants extend to show an imperative role in the rural healthcare system of developing countries, where herbal medicine has a continuous history of long use. Field studies were conducted following standard ethnobotanical techniques to collect information on the use of toxic and medicinal plants used by the Wancho tribe of Arunachal Pradesh. Vigna radiata was used as a plant model in this study to investigate the antiproliferative property of selected medicinal plant extracts. Green gram seedling root apical meristem cells were used to determine the inhibition of germination and slow growth. Different concentrations of plant extract $(20,50,250$ and $500 \mu \mathrm{g} / \mathrm{ml})$ were treated in a test tube containing the green gram seeds $(\mathrm{n}=5)$ on time dependent manner. Colchicine $(20 \mathrm{mg} / \mathrm{ml})$ was used as a standard drug for the growth retardation of green gram seedlings, while the distilled water group served as negative control. Germination test of Vigna radiata L. was performed according to ISTA (International Rules for Seed Testing) rules. The present study concludes that the methanolic plant extracts of all the collected plants significantly inhibited the rate of seed germination and seedling growth at dose dependent manner. It signifies that the use of Phlogacanthus parviflorus and Mikania micrantha in high concentrations may be potentially therapeutic for inhibiting the cell cycle in eukaryotic organisms.

Keywords: anti-proliferative; Arunachal Pradesh; medicine; plants; toxic; Wancho

\section{Introduction}

Plants are not only an essential part of health care but also ensures safe medicines for the future (Hamburger and Hostettmann, 1991). Most of the relevant drugs which have transformed the modern medicinal practice have been isolated from plants. However, just 1-10\% of all plant species on the planet have been chemically and pharmacologically investigated for their possible therapeutic benefits (Verpoorte, 2000). The chemical ingredients present in these medicinal herbal exhibit latent therapeutic properties. The plantderived compounds have also been a major source of many clinically effective antiproliferative agents (Agyare et al., 2013). The herbal extracts, which are an excellent scavenger of free radicals, have been used to treat a variety of diseases. It contains a variety of phytochemicals that work together to combat diseases that are resistant to purified compounds (Sharma, 2016). Flavopiridol, Epipodophyllotoxin, Noscapine, Paclitaxel,

Received: 03 Feb 2021. Received in revised form: 22 Apr 2021. Accepted: 07 May 2021. Published online: 12 May 2021.

From Volume 13, Issue 1, 2021, Notulae Scientia Biologicae journal uses article numbers in place of the traditional method of continuous pagination through the volume. The journal will continue to appear quarterly, as before, with four annual numbers. 
Vindesine, Vinorelbine, Vinflunine, Pomiferin, Roscovitine, Sulphoraphane, Vincristine, and Vinblastin are few examples of well-known plant derived anticancer drugs (Greenwell and Rahman, 2015; Pereira et al., 2016, Basu and Maier, 2018).

The expansion and recognition of these medicinal herbs including the monetary aids of these plants are on the rise in both developed and developing nations (WHO, 1998). These herbs can be easily accessed by the common man and recognized to be much safer than synthetic drugs available in markets (Singh and Singh, 1981). Therefore, the screening of biologically active agents of these herbal plant extracts had led to the discovery of many pharmaceutically important drugs (Rastogi and Meharotra, 1996).

In the state of Arunachal Pradesh, the use of medicinal and toxic plants in the healthcare system and fishing respectively is an integral part of tribal culture. Twenty-eight major different ethnic groups are residing in diverse regions of the state and they have distinct traditional knowledge on the use of plants (Tag and Das, 2004). Their perception and knowledge of using these assets, however, varied from tribe to tribe. With the use of these plants on daily basis, their belief in their native plants for medications or fishing has evolved. These toxic and medicinal plants used by the indigenous people may also have anti-proliferating property. Therefore, this study was an attempt to collect the information available on the medicinal and toxic plants used by the Wanchos of Longding District, Arunachal Pradesh and to evaluate their anti-proliferative activity.

\section{Materials and Methods}

\section{Study area and ethnic community}

The Longding district situated in the Patkai range is comprised of mountainous terrain flowed by streams and rivers cascading down from upper radiant elevation (Figure 1). The Patkai range constitutes the part of the Eastern Himalayan mountains. Due to the consistent wind, the region is cold and a blanket of mist often conceals the area. The Wanchos inhabiting the District are tribal, ethnically linked to the Konyak Naga of Nagaland. Their dialect belongs to the Tibeto-Burman ancestry. The majority of the population is agrarian. Oriah is the main festival, which is a celebration of the sowing season. The society is traditionally administered by a council of Wangham or Chieftains. Both males and females actively participate in agriculture and other activities. Tattooing plays a significant role in the tribe, which signifies the valour (award for hunting enemy's heads in the past) for men and the attainment of womanhood for women.

\section{Field study and data collection}

Field studies were conducted following the standard ethnobotanical techniques of Martin (1995). The ethnobotanical survey covers the Wancho inhabited villages. The plant-related data was collected through Participatory Rural Appraisal (PRA), based on personal interaction with the indigenous population and practical observation in the survey. Standard questionnaires were devised to obtain information on the uses of plants in fishing and in the treatment of various ailments. A total of 30 informants were interviewed to record their knowledge, skills, and practices on plant-based folk medicines and toxic plants. The group interview was conducted for a comparative statement. Identification of these medicinal plants was done by referring to the herbaria of Botanical Survey of India (BSI), Itanagar, and BSI (Kolkata) and also through consultation of taxonomic literature and Floras. The scientific names of the collected plant specimens were verified by visiting the "theplantlist.org" website. The voucher specimens were deposited to the Plant Systematic and Ethnobotany Lab of Rajiv Gandhi University, Rono Hills, Arunachal Pradesh.

\section{Preparation of plant extract}

The Medicinal plants were collected from the study site (Table 1) and the fresh plant parts were washed, shade-dried, and grounded to powder. Ten grams of powder were dissolved in $100 \mathrm{ml}$ of methanol overnight, filtered, and kept at $0{ }^{\circ} \mathrm{C}$ for further use. 


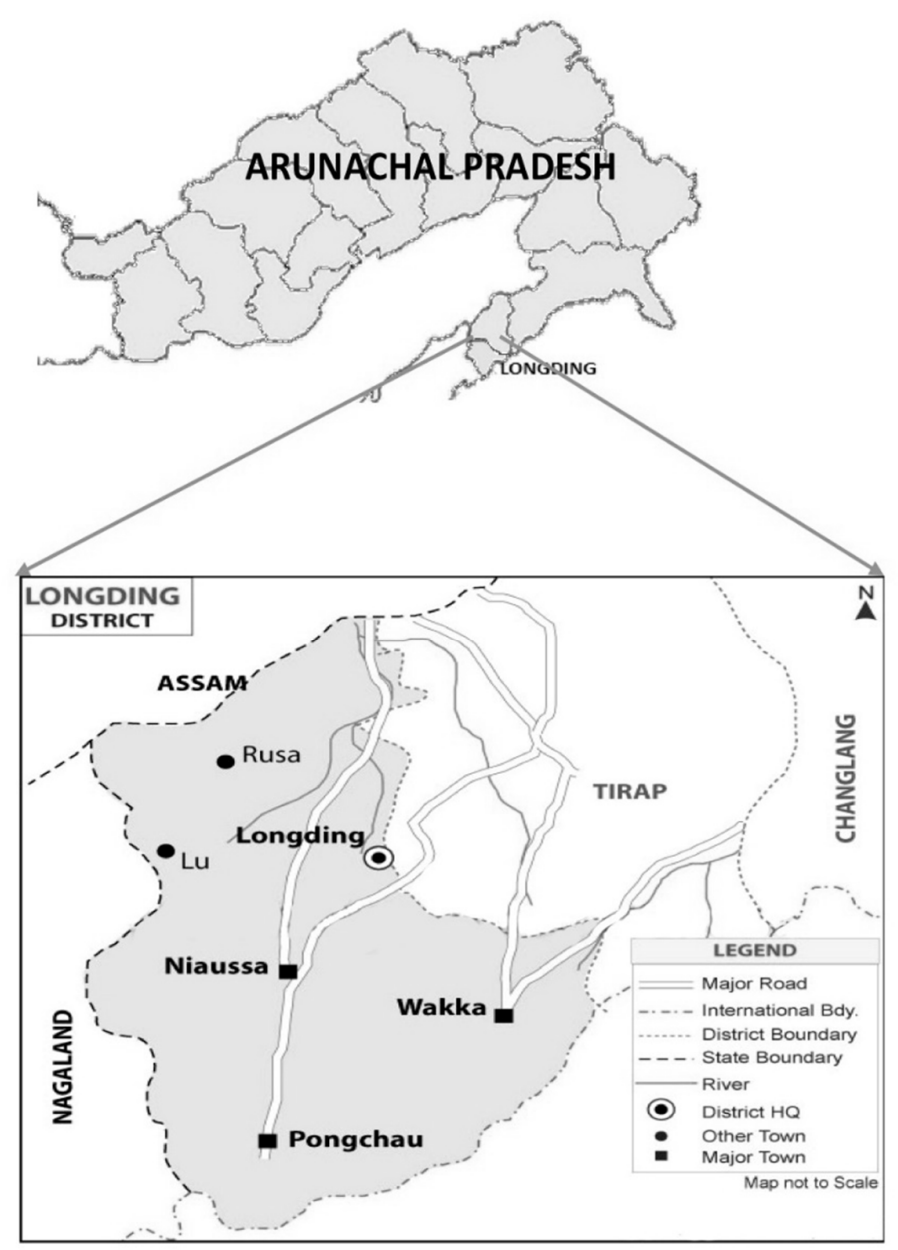

Figure 1. Map of Study area: Longding district of Arunachal Pradesh, India

Table 1. Enumeration of the medicinal and toxic plants used by Wancho community of Eastern Himalayas

\begin{tabular}{|c|c|c|c|c|c|c|c|}
\hline $\begin{array}{c}\text { Sl. } \\
\text { No. }\end{array}$ & Botanical names & Family & $\begin{array}{c}\text { Life } \\
\text { forms }\end{array}$ & $\begin{array}{c}\text { Vernacular } \\
\text { names }\end{array}$ & Parts used & $\begin{array}{c}\text { Mode of } \\
\text { use }\end{array}$ & Traditional uses \\
\hline 1. & $\begin{array}{c}\text { Mikania } \\
\text { micrantha }\end{array}$ & Asteraceae & Creeper & Zusa & Wp & Paste & $\begin{array}{c}\text { Wound healing, } \\
\text { stomach } \\
\text { disturbances }\end{array}$ \\
\hline 2. & $\begin{array}{c}\text { Ostodes } \\
\text { paniculata }\end{array}$ & Euphorbiaceae & Tree & Sojuh & Lv, Pt & Paste & Fish poisoning \\
\hline 3. & $\begin{array}{c}\text { Tithonia } \\
\text { diversifolia }\end{array}$ & Asteraceae & Shrub & Poshak & Lv & Decoction & $\begin{array}{c}\text { Anti- } \\
\text { inflammatory, anti- } \\
\text { oxidant }\end{array}$ \\
\hline 4. & $\begin{array}{c}\text { Blumea } \\
\text { balsamifera }\end{array}$ & Asteraceae & Herb & Mailong & Lv & Decoction & $\begin{array}{c}\text { Kidney diseases, } \\
\text { common cold }\end{array}$ \\
\hline 5. & $\begin{array}{c}\text { Acorus calanus } \\
\text { A. Acoraceae }\end{array}$ & Herb & Lannu & Wp & Decoction & $\begin{array}{c}\text { Gastrointestinal } \\
\text { disorders }\end{array}$ \\
\hline 7. & $\begin{array}{c}\text { Casearia zeylanica } \\
\text { Phlogacanthus }\end{array}$ & Salicaceae & Tree & Zookai & Lv, Pt & Paste & Fish poisoning \\
\hline
\end{tabular}

Note: Wp: whole plant, Lv: leaves, Pt: Petiole, Br: Bark 


\section{Experimental plant model}

Good quality and diseased free Vigna radiata L. (green gram) were used as a model plant. Green gram seedling root apical meristem cells were used to determine the inhibition of germination and slow growth. Colchicine $(20 \mathrm{mg} / \mathrm{ml})$ is used as a standard drug for the growth retardation of green gram seedlings.

\section{Treatment of Vigna radiata L. seedlings}

Germination test of green gram was performed following standard rules (International Rules for Seed Testing, 2018). For the germination of seeds, different concentrations $(20,50$, and $250 \mu \mathrm{g} / \mathrm{ml}$ ) of plants extract treated with methanol were placed in a test tube, and the seeds of green gram $(n=5)$ were added into each tube. The tubes were closed and the plant was allowed to germinate at room temperature. Colchicine $(20 \mathrm{mg} / \mathrm{ml})$ treated group served as a positive control, while the distilled water as negative control (Ray et al., 2013). Seed germination and root length were measured after 72 hours both in control and test groups.

\section{Results and Discussion}

\section{Taxonomic evaluation of the collected medicinal plants}

A total of seven medicinal and toxic plants belonging to five plant families were collected and identified (Figure 2). Life forms consist of herbs (3 plants), trees ( 2 plants), shrubs (1 plant), and creepers (1 plant). Among the plant parts used, the leaves were most commonly used. The rest of the plant parts includes the petiole and the whole plant. The collected medicinal plants were found to be used in several ailments including wound healing, stomach disorders, anti-inflammatory, kidney diseases, common cold, gastrointestinal disorders, gastrointestinal disorders, and chest pain. While the toxic plants were actively used in traditional fish poisoning. The medicinal plants were administered through the preparation of decoction. Whereas, the paste of toxic plants was directly poured into the runner water while fishing.

\section{Effects on seed germination and root length}

This study evaluated the anti-proliferative potential of seven plants, prescribed mostly by traditional healers for various ailments. The methanolic plant extracts investigated in this study revealed dose inhibitory effects on seed germination and root length in $V$. radiata. A higher concentration of plant extracts $(500 \mu \mathrm{g} / \mathrm{ml})$ inhibited seed germination compared to the negative control of respective groups (Figure 3). $250 \mu \mathrm{g} / \mathrm{ml}$ of plant extracts treated group also inhibits the germination of green gram seeds at 72 hours of treatment when compared with the negative control (Figure 4). On the other hand, the colchicine $(20 \mathrm{mg} / \mathrm{ml})$ induced group showed the complete retardation of root growth in 24,48 , and 72 hours' time interval when compared to all the respective groups (Figure 4).

The lowest concentration $(20 \mu \mathrm{g} / \mathrm{ml})$ of plant extract of all plant species did not exhibit much effect on the germination and root length of green gram saplings. $50 \mu \mathrm{g} / \mathrm{ml}$ concentration, however, showed little effect and decreased the root length. $250 \mu \mathrm{g} / \mathrm{ml}$ concentration also exhibited a decrease in root length; while some plant (Mikania micrantha and Phlogacanthus parviflorus) extracts have shown complete retardation of root growth. The highest concentration $(500 \mu \mathrm{g} / \mathrm{ml})$ of methanolic extract of five plants exhibited high antiproliferative potential. These plants were $P$. parviflorus, $C$. zeylanica, M. micrantha, B. balsamifera and $T$. diversifolia. On the contrary, the plant species Ostodes paniculata displayed ample growth of radicles in every dose. Thus, it is least effective than other competitors. According to Handa et al. (1983), the isolated compounds from the plant parts of Ostodes paniculata display significant in vitro cytotoxic effect on cancer cell lines. Considering this, it may be assumed that all other plants, showing better result than $O$. paniculata in current study may exhibit effective results with the cell line in vitro. 

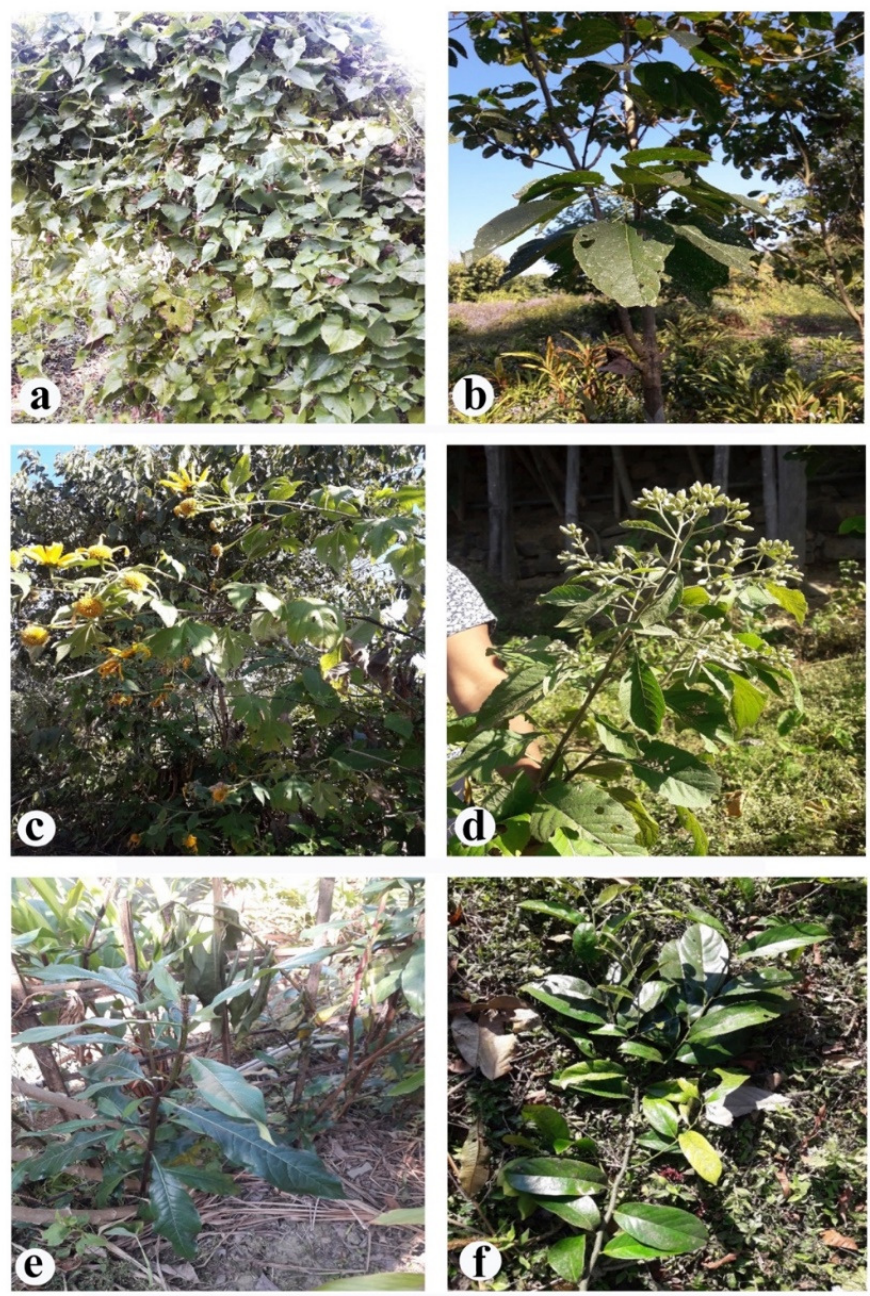

Figure 2. Some of the medicinal and toxic plants used by Wancho tribe of Arunachal Pradesh: (a) Mikania micrantha, (b) Ostodes paniculata, (c) Tithonia diversifolia, (d) Blumea balsamifera, (e) Phlogacanthus parviflorus, and (f) Casearia zeylanica 


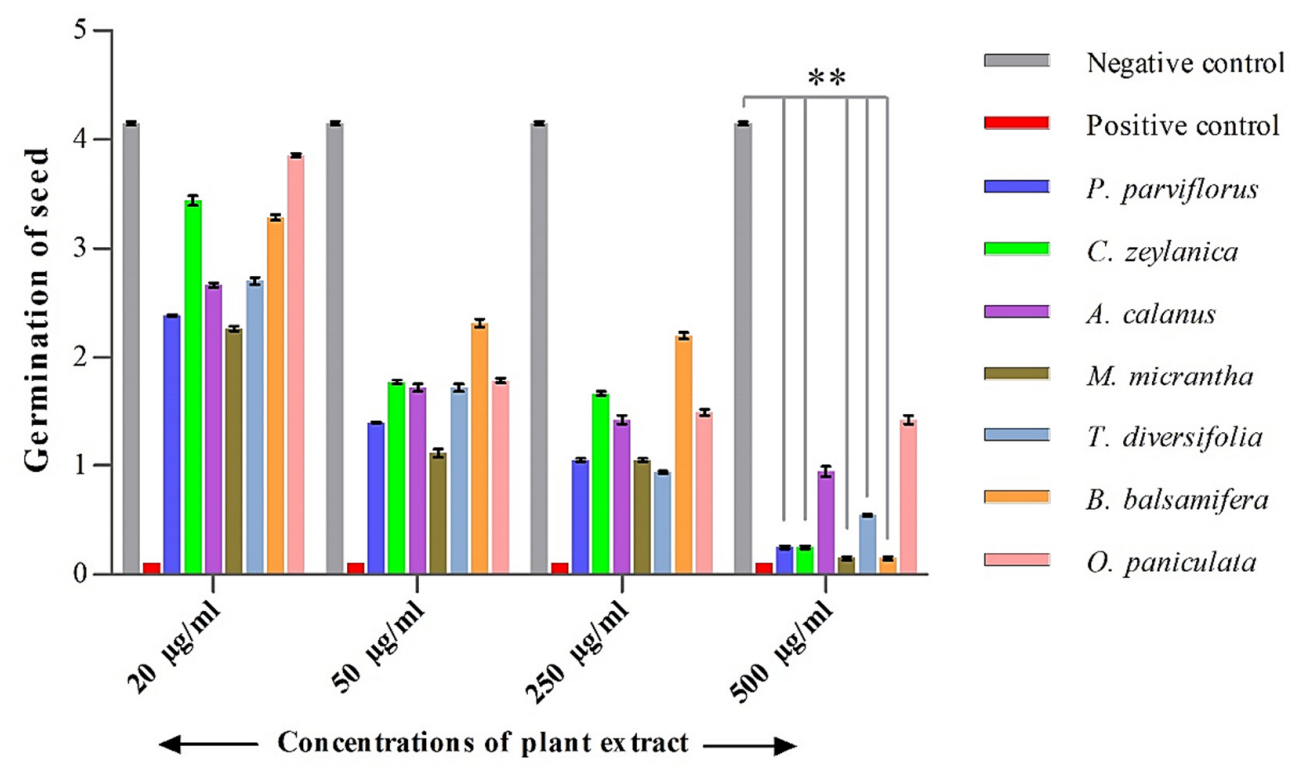

Figure 3. Effect of different methanolic plant extracts on the seed germination of Vigna radiata Mean $\pm \operatorname{SEM}(\mathrm{n}=5)$. Two-way ANOVA followed by Bonferroni's post-test. Significance set at $P<0.05$. " $P<0.01$ compared to negative control.

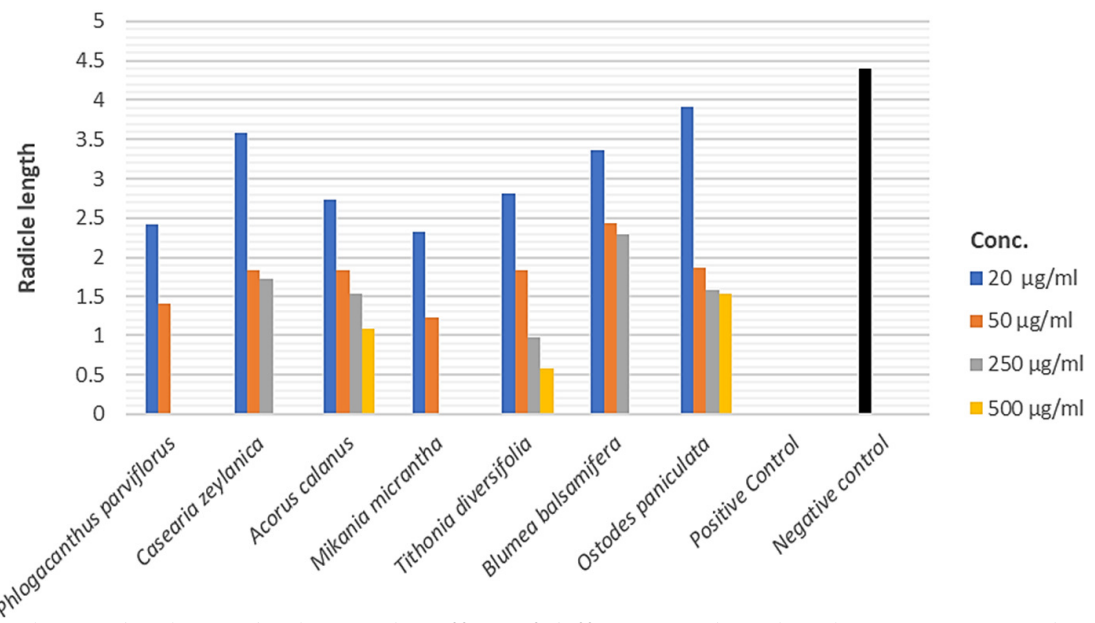

Figure 4. Clustered column displaying the effect of different methanolic plant extracts on the radicle length of Vigna radiata seeds

Several previous studies have reported the antiproliferative activity of different medicinal plant in $V$. radiata model (Charchafchi et al., 2007; Fawzia et al., 2007; Ray et al., 2013; Chetry and Bahrali, 2018). It was also reported that the essential oil extracted from the invasive weed M. micranthaflower has been found to have antimicrobial and anticancer properties (Saikia et al., 2020). The plant M. mirantha was also reported to possess anti-tumour activity (Dou et al., 2014). On the other hand, the whole plant and crude extracts, as well as its isolated constituents of $B$. balsamifera display numerous biological activities, such as antitumor, hepatoprotective, superoxide radical scavenging, antioxidant, antimicrobial and anti-inflammation, antiplasmodial, anti-tyrosinase, platelet aggregation, enhancing percutaneous penetration, wound healing, antiobesity, along with disease and insect resistant activities (Pang et al., 2014). 
The anti-proliferative activity of the plant species $P$. parviflorus was not previously reported. However, other species of this genus ( $P$. thyrsiflorus) were reported with the anti-cancerous along with other properties such as antibacterial, antifungal, anti-diabetic, anti-inflammatory, anti-cancerous, hypolipidaemic and hepatoprotective (Singh and Singh, 2010). It was reported that the leaves and flowers of $P$. parviflorus are traditionally cooked and consumed as vegetables; while, the decoction of the leaves helps in curing fever, cold and sore throat (Dutta and Nath 2019).

On the other hand, even though some workers have described the manifold uses of the medicinal or toxic plants, there is still a need of doing much work in this field (Perme et al., 2015). Moreover, the present research was a preliminary investigation on the potential of locally available herbal toxic and medicinal plants extracts, which must be supported and validated further by performing the in vivo anti-proliferative activity was evaluating the tumour inhibitory rates in cell line or thymus index and spleen index of S180-bearing mice (Dou et al., 2014).

\section{Conclusions}

The present study concludes that the methanolic plant extracts of all the collected plants significantly inhibited the rate of seed germination and seedling growth. It signifies that the use of Phlogacanthus parviflorus and Mikania micrantha in high concentrations may be potentially therapeutic for inhibiting the cell cycle in eukaryotic organisms. Thus, these two plants may contain strong anti-proliferative agents for the management of proliferative diseases such as cancer progression. However, further research will be needed to isolate the active compounds and to determine their influence on the cell cycle regulatory gene expression.

\section{Authors' Contributions}

TW: guided and drafted the manuscript. AW: performed the experiment. LBC: analysed data and edited the manuscript. ST: supervision. All authors read and approved the final manuscript.

\section{Acknowledgements}

The authors acknowledge the Wanchos for sharing their valuable knowledge.

\section{Conflict of Interests}

The authors declare that there are no conflicts of interest related to this article.

\section{References}

Agyare C, Obiri DD, Boakye YD, Osafo N (2013). Analgesic activities of African medicinal plants. In: Medicinal Plant Research in Africa. USA: Elsevier Inc. pp 726.

Basu P, Maier C (2018). Phytoestrogens and breast cancer: In-vitro anticancer activities of isoflavones, lignans, coumestans, stilbenes and their analogs and derivatives. Biomedicine \& Pharmacotherapy 107:1648-1666. https://doi.org/10.1016/j.biopha.2018.08.100 
Charchafchi FA, Al-Nabhani I, Al-Kharousi H, Al-Quraini F, Al-Hanai A (2007). Effect of aqueous extract of Azadirachta indica (Neem) leaves on germination and seedling growth of Vigna radiata (L.). Pakistan Journal of Biological Science 10(21):3885-3889. https://doi.org/10.3923/pjbs.2007.3885.3889

Chetry LB, Bharali MK (2018). Antiproliferative effect of aqueous bark extract of Oroxylum indicum L. on Vigna radiata L. (Green gram) seedlings. The Journal of Phytopharmacology 7(2):175-179.

Dou X, Zhang Y, Sun N, Wu Y, Li L (2014). The anti-tumor activity of Mikania micrantha aqueous extract in vitro and in vivo. Cytotechnology 66(1):107-117. https://doi.org/10.1007/s10616-013-9543-9

Dutta B, Nath N (2019). Phlogacanthus parviflorus T. Anders (Acanthaceae): a new addition to the flora of Assam. Journal of Emerging Technologies and Innovative Research 6(5):85-87.

Fawzia, Al-Charchafchi MR, Al-Shuhumi H, Al-Meselhy S, Al-Busadi M, Al-Shuhumi H (2007) Biological activity of seed aqueous extract of Nigella sativa (L.) on germination and seedling growth of Vigna radiata (L.). Pakistan Journal of Biological Science 10(23):4319-22.

Greenwell M, Rahman PKSM (2015). Medicinal plants: their use in anticancer treatment. International Journal of Pharmaceutical Sciences and Research 6(10):4103. https://doi.org/10.13040/IJPSR.0975-8232.6(10).4103-12

Hamburger M, Hostettmann K (1991). Bioactivity in plants: the link between phytochemistry and medicine. Phytochemistry 30:3864-3874. https://doi.org/10.1016/0031-9422(91)83425-K

Handa SS, Kinghorn AD, Cordell GA, Farnsworth NR (1983). Plant anticancer agents. XXII. Isolation of a phorbol diester and its delta 5,6-7 beta-hydroperoxide derivative from Ostodes paniculata. Journal of Natural Products 46(1):123-6. https://doi.org/10.1021/np50025a013

ISTA (2017). International Rules for Seed Testing 2018. Including changes and editorial corrections adopted at the ordinary general meeting, Denver, USA.

Martin G (1995). Ethnobotany - A manual of methods. London: Earthscan Publishers Limited.

Nimasow G, Rawat JS, Arunachalam A, Dai O (2011). Ethno-medicine of Aka Tribe, West Kameng district Arunachal Pradesh (India). Science and Culture 77:3-4.

Pang Y, Wang D, Fan Z, Chen X, Yu F, Hu X, ... Yuan L (2014). Blumea balsamifera-a phytochemical and pharmacological review. Molecules 19(7):9453-9477. https://doi.org/10.3390/molecules 19079453

Pereira A, Bester M, Soundy P, Apostolides Z (2016). Anti-proliferative properties of commercial Pelargonium sidoides tincture, with cell-cycle G0/G1 arrest and apoptosis in Jurkat leukaemia. Pharmaceutical Biology 54(9):18311840. https://doi.org/10.3109/13880209.2015.1129545

Perme N, Choudhury SN, Choudhury R, Natung T, De B (2015). Medicinal plants in traditional use at Arunachal Pradesh, India. International Journal of Phytopharmacy 5(5):86-98. https://doi.org/10.7439/ijpp.v5i5.2863

Rastogi PR, Meharotra BN (1996). In Compendium of Indian Medicinal Plants. Vol. I, 339; III: 194. PID, CSIR, New Delhi, India.

Ray S, Chatterjee S, Chakrabarti CS (2013). Antiproliferative activity of allelochemicals present in aqueous extract of Synedrella nodiflora (L.) Gaertn. in apical meristems and Wistar rat bone marrow cells. OSR Journal of Pharmacy 3(2):1-10. https://doi.org/10.9790/3013-3220110

Saikia S, Tamuli KJ, Narzary B, Banik D, Bordoloi M (2020). Chemical characterization, antimicrobial activity, and cytotoxic activity of Mikania micranthaKunth flower essential oil from North East India. Chemistry Papers 74:2515-2528. https://doi.org/10.1007/s11696-020-01077-6

Sharma M (2016). Selective cytotoxicity and modulation of apoptotic signature of breast cancer cells by Pithecellobium dulce leaf extracts. Biotechnology Progress 32:756-766. https://doi.org/10.1002/btpr.2261

Singh P, Singh CL (1981). Chemical investigations of Clerodendraon fragrans. Journal of Indian Chemical Society 58:626-627.

Singh SA, Singh NR (2010). Antimicrobial activity of Cassia didymobotrya and Phlogacanthus thyrsiflorus. Journal of Chemical and Pharmaceutical Research 2(4):304-308.

Tag H, Das AK (2004). Ethnobotanical note on the Hill Miri tribe of Arunachal Pradesh. Indian Journal of Traditional Knowledge 3(1):80-85.

Talib WH, Mahasneh AM (2010). Antiproliferative activity of plant extracts used against cancer in traditional medicine. Scientia Pharmaceutica 78(1):33-45. https://doi.org/10.3797/scipharm.0912-11

Verpoorte R (2000). Pharmacognosy in the new millennium: lead finding and biotechnology. Journal of Pharmacy and Pharmacology 52(3):253-62. https://doi.org/10.1211/0022357001773931

WHO (1998). Regulatory situation of herbal medicines. A worldwide review. Geneva, Switzerland, pp 1-5. 
OPEN The journal offers free, immediate, and unrestricted access to peer-reviewed research and scholarly work. Users are allowed to read, download, copy, distribute, print, search, or link to the full texts of the articles, or use them for any other lawful purpose, without asking prior permission from the publisher or the author.

(c) (P)

License - Articles published in Notulae Scientia Biologicae are Open-Access, distributed under the terms and conditions of the Creative Commons Attribution (CC BY 4.0) License.

(c) Articles by the authors; SHST, Cluj-Napoca, Romania. The journal allows the author(s) to hold the copyright/to retain publishing rights without restriction. 